\title{
History of Medicine
}

Joseph A. MacDougall B SC MD CRCPC

Literature relaring the early history of ether anaesthesia in New Brunswick which, as part of British North America was a British colony unill 1867, is reviewed. There is documentary evidence that the first ether antaesthetic for dental surgery in what is now Canada, was administered in 1844 in St.John, New Brunswick. There is also documentary evidence that the first ether anaesthetic for general surgery was administered in St. John on Monday, January 18, 1847, rather than in Montreal in March, 1847.

Credit for the first use of ether anaesthesia probably belongs to Crawford Long in 1842.' However, W.E. Clarke had also administered ether for a dental extraction in Rochester, New York in January, $1842,{ }^{2}$ two months before Long used it in Jefferson, Georgia. The use of this agent did not become widespread until four years later following the first public demonstration of ether anaesthesia by William Morton at the Massachusettes General Hospital. On October 16, 1846, Morton administered ether ("Letheon") to Gilbert Abbott for the excision of a neck tumour by John C. Warren, Professor of Surgery at Harvard. ${ }^{3}$ The news of surgical operations performed during insensibility spread rapidly. Reports of the use of ether appeared in medical journals and the lay press of the Eastern United States. There is also substantial agreement that ether was first used in Britain on December 19, 1846, in London and Dumfries simultaneously. ${ }^{4}$ There is no agreement, however, on its first use in Canada. Evidence published to date is inconclusive. Matsuki, in his detailed history of ether anaesthesia in Canada gives a verified chronology. ${ }^{5}$

From the Department of Anaesthesia, Saint John Regional Hospilal, P.O. Box 2100, Saint John, New Brunswick, E2L 4L2.
The earliest ether anaesthetic in British North America - a first for Saint John, New Brunswick?

Evidence which suggests ether was first used in St. John* New Brunswick is presented here.

\section{Documentary Evidence}

On December I, 1846, the British American Journal of Medicine and Physical Science announced in its column, "Books etc. Received during the Month," reception of the November 18th issue of the Boston Medical and Surgical Joumal which included H.J. Bigelow's paper on ether anaesthesia. ${ }^{6}$ This is the first information on ether published in Canada. In its following issue, the first of next year, the same Journal, ${ }^{7}$ published a countervailing, rather negative article, entitled "Insensibility During Surgical Operations Produced by Inhalation." This was extracted from the December 1846 issue of the Philadelphia Medical Examiner. The medical profession, it suggested, would not be taken in by this apparent hoax. Also in January, 1847, a Montreal dentist called Webster purchased an ether inhaler from a "chevalier d'industrie." With a Dr. Horace Nelson, Webster experimented with ether anaesthesia in dogs. They also administered ether to each other and in March 1847, Dr. Wolfred Nelson (Horace Nelson's father) successfully removed a large tumour from a woman anaesthetized with ether by $\mathrm{Mr}$. Webster. The precise date of this operation is not known, but if it took place before March $8,1847,{ }^{8}$ it precedes the case of Dr. Worthington of Sherbrooke, who on March 11 or 14,1847 , amputated the foot of a 30 -year-old man under ether anaesthesia using a large ox-bladder with a stop-cock as an inhalcr. ${ }^{9}$ Jacques believed that this was the first ether anaesthetic in Canada. ${ }^{10} \ln$ March, 1847 ,

*In the Charter of the Cily of Saint John the word "Saint" is spelled in full. For many years, however, it was abbreviated by Jocal custom to St. John. On April 25, 1925. City Common Council decided to revert to the original Saint, to distinguish their City from St. John's, Newfoundland and St. John, Quebec. 


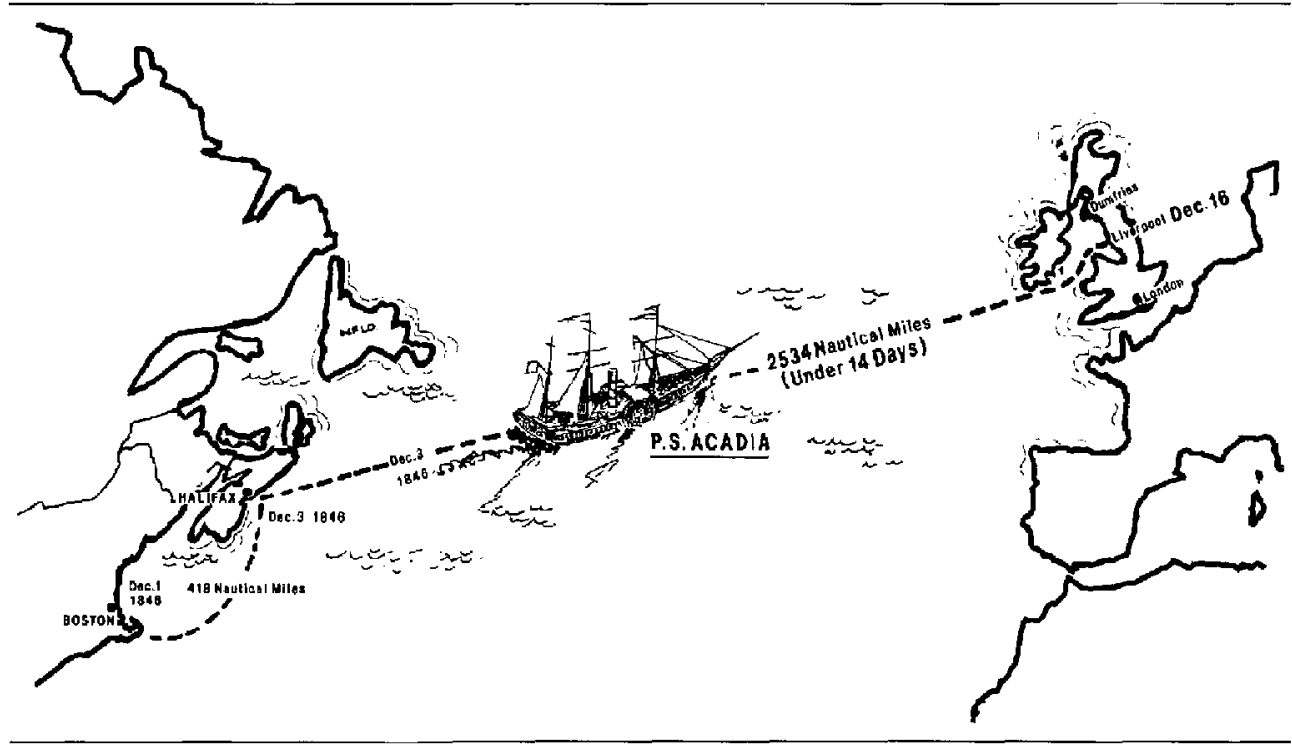

FIGURE 1 Movements of the P.S. Acadia December 1-16, 1846.

Dr. James Douglass of Quebec amputated the toes of a man under ether anaesthesia. "This anaesthetic, which precedes Dr. Nelson's, was previously thought to have been the first in Canada, the conclusion being based largely on inference, from an unscientific differentiation dependent upon the terms "lately" and "more lately."11

Not surprisingly, there were also failures: Dr. Campbell at the Montreal General Hospital failed to anaesthetize a patient with ether. " His report, together with editorial comment, appeared in the same issue of the journal. ${ }^{12}$ By September 6, 1847, Dr. J. Crawford of McGill College had tried unsuccessfully to use ether for sedating a patient with traumatic tetanus before successfully anaesthetizing a 14-year-old boy for the amputation of a leg. ${ }^{13}$

Today we know that the news of ether anaesihesia spread quickly from Boston. Dr. Bigelow's paper encouraged many to try ether. Wright states:

News of ether anaesthesia had first reached Britain through the Boston Medical and Surgical journal and Dr. Begelow's letter to his friend Dr. Boott, which was carried in the Acadia from Boston to Liverpool, arriving on December 16, 1846.

Sykes ${ }^{15}$ and Ellis ${ }^{16}$ (1958) explored possible travel arrangements in considerable detail. Through Sykes we are indebted to the Cunard Shipping Line for the following information:
"We have established from our sailing records that the Acadia, one of the four wooden paddle steamers with which Samuel Cunard and his partners inaugurated their steamship services between Britain and North America in 1840, arrived at Liverpool on December 16, 1846. Her voyage took just under 14 days, the average approximate time taken by Atlantic Steamers during the 1840's."

Further, the Deputy Keeper of the South Kensington Science Museum stated:

"We have a note that in 1847 The Cunard P.S. (paddle steamer) Hibernia (1843) crossed from Halifax to Liverpool in 9 days 1 hour 30 minutes at a mean speed of 11.67 knots. This was however, a record at the time for the normal service speed of the vessel is stated to have been about 9.25 knots."

At her usual speed, the Acadia would have taken about eleven and a half days from Halifax (Figure 1). The reference to Halifax confirms that in 1846-1847 the four ships of the British and North American Steam Packet Company sailed regularly between Liverpool and Boston, calling at Halifax on the outward and return voyages. This is suggested in, "Warden of the North" by Raddall. " In 1846 Joseph Howe, pushing for an extension of the telegraph from St. John to Halifax, suggested that Halifax could become a clearing house for world news, "as the 


\title{
New abertisementw. Dentistical Operations,
}

\author{
ander the infuepere of the \\ GTERERAI, VAPDUR,

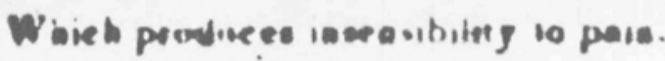

DI R. VAN BUSKIRK bee operated on

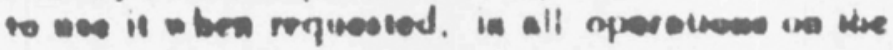
1000th.

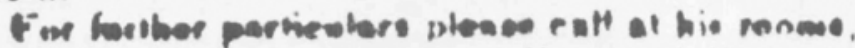

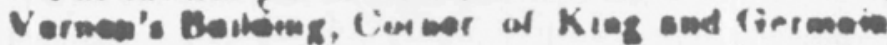
Nireale. Jan is

FIGURE 2 Dentistical Operations: The New Brunswick Courier, Saturday, January 23, 1847.

first point of west bound Cunarders and the last port of the east bound." 17

The following documentary evidence indicates the movements of the P.S. Acadia in December, 1846.

"Cleared—Boston—Tuesday, December 1st, 1846." "Arrived-Halifax early morning Thursday, December 3rd, 43 hours after leaving Boston." "Cleared-Halifax, same day. Thursday December 3rd, 1846."18

"Arrived-Liverpool, December 16, 1846."15

Mail from Halifax, which would have been cleated on Thursday, December 3, arrived in St. John at 10 pm, on the following Monday night, five days later. Ordinarily the mail came express which took two days, but in December 1846, the buget for this service had run out for the year and the ordinary mail was used. This took two to three days longer. ${ }^{19}$

On Friday December 18, 1846, one of the seventeen St. John newspapers, ${ }^{20}$ the Weekly Chronicle printed the entire article: ${ }^{3}$

\author{
"Insensibility During Surgical \\ Operations Produced By Inhalation" \\ Read before the Boston Society of Medical \\ Improvement. November 9, 1846 \\ an abstract having \\ been previously read before \\ the American Academy
}

of Arts and Sciences, November 3rd, 1846.

By Henry Jacob Bigelow M.D., one of the surgeons of

the Massachusettes General Hospital.

(From the Boston Medical and Surgical Journal)

On Saturday, January 23, 1847, the New Brunswick Courier, printed the notice illustrated in Figure 2.

This notice was repeated weekly at least until March 20,1847, and was also carried in the Saint John Morning News from January 25 three times weekly for several months.

On Friday September 8, 1905, the Saint John Globe 21 reported a paper on the early history of Dentistry in St. John, written and read by Dr. A.F. McAvenney before the 
Two brothers nnmed Vanbuskirk practiced dentiatry here in 1840. 'The tirst time that efluer was adninistered in st. John for extractum teeth was in the office of the I'anblakirke by Dr. Win. Bayard. Dr. Bayard tells a very ammaing story of all the precenutions he took with his lndy patient, and also the pre. perations made by the dentists in cave the patient gave signs of being at all unruly. If she had been a raving maniac ahe could not hare been more closely secured before they atempted to acimin. inter the anaestleetic. This was in $\mathbf{1 8 1 4}$ shortly after Dr. Horace Wells, the American dentist, discovered surgical anaesthesia. One of the Vanbuskirh orothers married Miss Reid, daughter of a proituinent pilot. Miss Reid at that time was considered the handsomest lady in St. Jolnn. The Vanbuskırks Jeft St. John in the early fifties, ove going to Halifax, the other to Montreal.

FIGURE 3 The Saint John Globe, Friday, September B, 1905. From: A paper on the early history of dentistry in St. John written and read by Dr. A.F. McAvenncy, before the Dental Association of Halifax on Weinesday, September 6, 1905.

Dental Association of Halifax and subsequently published in the Dominion Dental Journal ${ }^{22}$ (Figure 3). In the 57 years reviewed, between 1823 and 1880, Dr. McAvenney mentions aproximately 30 dentists. No details are given about eight who practiced for short periods. All but two of the remainder were either from the United States or local men trained in the United States. Most were both dentists and physicians. Three were trained in New York and all the remainder were trained in Boston or Philadelphia. Dr. McAvenney specifically mentions the name VanBuskirk:

A record of the use of an anaesthetic in St. John for general surgery appeared in The Weekly Chronicle (St. John), Friday, January 22, 1847 23 (Figure 4) and the
Phoenix Advertiser (St. John) Saturday, January 23, 1847 (Figure 5). ${ }^{24}$

This information indicates that ether anaesthesia was used in an operation which took place in St. John, New Brunswick on Monday, January 18, 1847, 20 days before Dr. Nelson's operation in Montreal and at least 16 days before Dr. Douglas' amputation in Quebec. It also preceded by a greater margin, Dr. Worthington's amputa. tion in Sherbrooke.

Dr. Martin Hunter Peters the surgeon, was the 12th child of Charles Jeffery Peters who landed in St. John on May 18, 1783, two years after the end of the American Revoluton. Charles Peters, who was born in New York, 


\section{TEม CIROXIOT.}

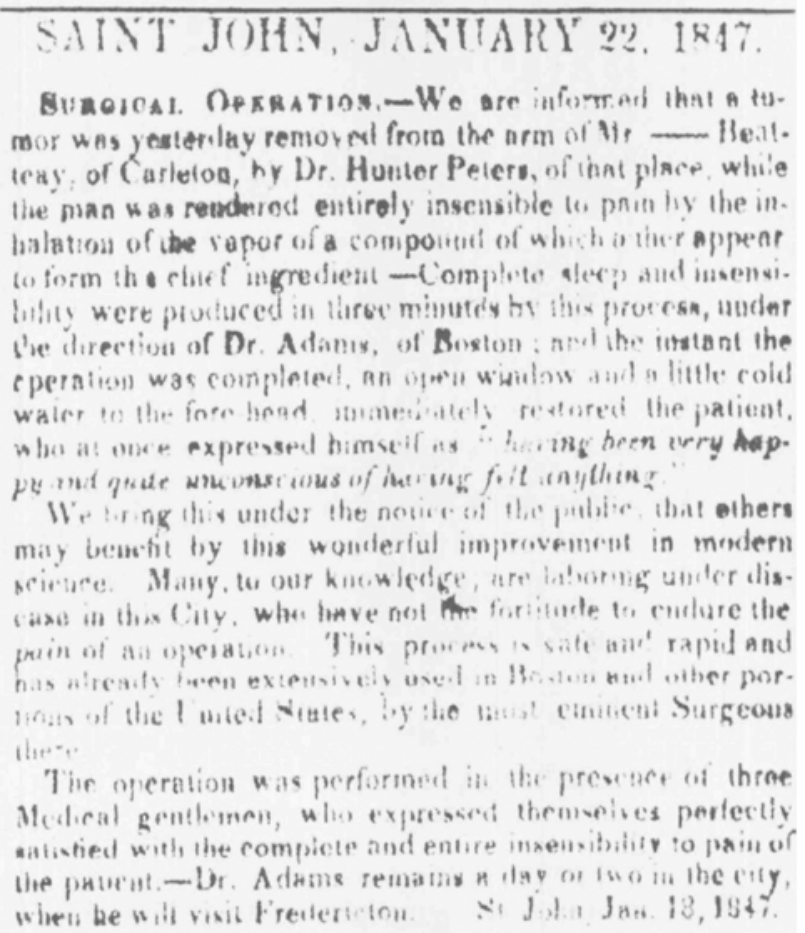

FIGURE 4 The Weekly Chronicle (St. John) Friday, January 22, 1847. Copied from the Weekly Observer (St. John) Tuesday, January 19, 1847.

was ten years old at the time. Dr. Martin Peter's home and office where the anaesthetic took place was built for him by his father, who was a very successful lawyer. The home, Gothic Cottage in design, is still an attractive and interesting home (Figure 6). Dr. Martin Hunter Peters was a Lt. Colonel in the Militia and was made a Freeman of the City.

Dr. George P. Peters, one of the witnesses, was a brother of Dr. Martin H. Peter's and the eighth child in the family. Both were graduates of Edinburgh University. Dr. George Peters served on the Licensing Board appointed by the Lieutenant Governor to check doctors for character and competence before granting or refusing a license. He became the Superintendent of the First Mental Hospital in British North America. ${ }^{33}$

Dr. Cyrus Fiske was a native of Salem, Massachusettes, a Harvard graduate in Medicine and Dentistry and one of many itinerate physicians who practiced Dentistry at that time. He was married on June 19, 1845, in St. Andrews, N.B. while practicing Medicine in Salem. ${ }^{25}$ In the New Brunswick Courier December 6 , 1845, under Dentistry a notice appeared informing the public that "Dr. Fiske will visit the City in a few days and will be prepared to offer all types of dental services." 26 Also, in the N.B. Courier, December 12, 1846, there is a description of an anaesthetic (ether) given by Dr. Fiske in Salem, Mass. This was copied from the Salem Register. This anaesthetic took place on Thursday afternoon, November $19,1846 .{ }^{27}$ In the N.B. Courier of December 12,1846 there appears a prominent first page notice "Dr. Fiske, Surgeon, Dentist and manufacturer of Mineral teeth - one door North of Mann's Hotel, Germain Street." 28 This is dated September 19. Dr. Fiske became a successful dentist, occulist and aurist. 


N O T I C E.
Dit. FISKE, Dentul Surgeon, of this City,
has procured the "LETHEON," a vapor
administered to produce insensibility during
Dental and Surgical Operations, and he will
make use of it in all operations upon the
mouth where it will apply. He wiil also
direct in its use for other Surgeons, (for
surgical operations) when desired.
An operation was recently performed for
removing a tumor fiom the arm at his oflice.
ly Di. Peters, of Carleton, in preseice of Drs.
Peters and Fitch, of this City, and other gen-
tlemen; the result was satisfactory to all par-
tics, and the suspension of sensibility perfect.
Ni. Juhn, January 23 , 1847 .

FIGURE 5 The Phoenix Advertiser (St. John), Saturday, January 23, 1847

The N.B. Courier of April 2, 1842, describes Dr. Simon Fitch in the following notice; "Dr. Simon Fitch a graduate of Edinburgh University; member of the Medical Society of Paris and late sole house surgeon to the General

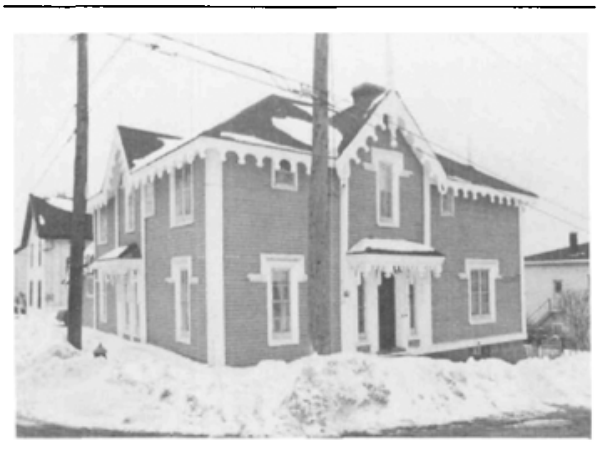

FIGURE 6 Home of Dr. Martin Hunter Peters, corner of Watson and Gilford Streets. Then Carleton, now Saint John West (With kind permission of Mr. and Mrs. W. Foster Hammond)
Lying-in wards of Edinburgh, begs leave to offer his services in every department of his profession, to the inhabitants of St. John and its vicinity. Residence and office in the building formerly occupied as the Post Office - corner of Germain and Princess. Advice to Poor gratis." 29

The fourth physician mentioned is Dr. Samuel Adams, a visiting consultant in anaesthesia. To date this is all the information about this elusive gentleman, but the name appears in two other interesting references. In his article, "Early History of Anaesthesia in Newfoundland," Wright ${ }^{14}$ mentions an advertisement in The Public Ledger (St. John's Newfoundland) of November 16, 1847, by a Dr. S. Adams, a Surgeon Dentist visiting St. John's for two weeks, presumably from the mainland. On November 26 , 1847, a William L. McKay, a Chemist and Druggist, placed a notice in The Public Ledger (St. John's Newfoundland), November 28, 1847 (Figure 7). Was this Dr. Samuel Adams of Boston visiting again?

Ellis, is convinced that the news of ether was discussed by Dr. William Fraser the ship's surgeon and some of the passengers during the Acadia's voyage. It must have been spread further by someone aboard when the vessel arrived 


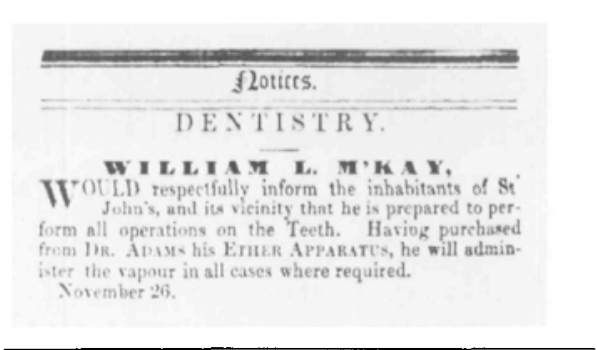

FGURE 7 The Public Ledger (St. John's Newfoundland), November $28,1847$.

in Liverpool because on Friday, December 18, 1846, a preliminary account appeared in the Liverpool Mercury. ${ }^{16}$

In the Halifax newspaper, The Nova Scotian of December 7, 1846, under passengers, four of the 43 passengers going from Boston to Liverpool on the Acadia are listed - one name was Adams. ${ }^{30}$

From the Saint John Globe (New Brunswick) of March 22,1847 , there is a report of an operation performed by Dr. William Bayard quoted directly here:

"Experience is establishing the beneficial effects of ethereal vapour during surgical operations, and the use of it is receiving the highest professional sanction in Europe and the United States. In our own city the experiments which have been already made, are confirmatory of the advantages of it. The inhalation of the vapour may or may not occasion sleep, but even though it fails in some instances to produce sleep, it nevertheless causes either an unconsciousness of pain, or, a total disregard of it. This fact was fully illustrated during an operation recently performed by Dr. William Bayard in the Hospital of this City and County (most llkely the Alms House). The operation under ordinary circumstances must have occasioned very great pain. The patient inhaled the vapour of ether through a machine made by Mr. Van Buskirk the dentist, who was present. A large quantity was Inhaled, exciting the most agreeable sensation, but the man said it would not make him sleep and asked for some brandy, saying that it would affect him. A little was given him, and he again inhaled the vapour, manifesting the same pleasurable sensations. He then told the doctor to "cut away"; when he saw the knife applied he seemed sensible of it at the time, but he laughed and talked during the operation, and slapping the doctor on the shoulder he said: "cut away doctor, you cut like a gentleman." The effects of the vapour in this case were somewhat similar to those reported by Professor Miller of the Royal Infirmary in Edinburgh. In his case the man, though perfectly awake, was unconscious of pain during the performance of an operation, whilst his attention was engaged in conversation with those around him and it is probable that a similar degree of uinconsciousness would have characterized the operation in our hospital if the patient had been blindfolded, or, if the knife could have been applied without his seeing it at the moment." ${ }^{\text {.31 }}$

Bayard was the son of Dr. Robert Bayard, a former professor of midwifery at the University of Ncw York, who refused to take the oath of allegiance to the United States in 1812 and returned to Canada. Dr. Robert Bayard was a son of Major Samuel Bayard of the King's Orange Rangers. Dr. William Bayard graduated from Edinburgh in 1837. He was the father of the General Public Hospital and first President of the N.B. Medical Society from 1867 to 1871 a post to which he was re-elected in $1880-1881$, 1890-1891 and 1899-1900. He was the first President of the Medical Council of New Brunswick, July, 1881, first President of the Maritime Medical Association, 1879, and President of the Canadian Medical Association in 1894. $\mathrm{He}$ served as Coroner and Chairman of the Board of Health for many years. A good speaker and lucid writer, who contributed articles to the Montreal Surgical Journal, the Maritime News and the New Brunswick Agriculturist. ${ }^{32} \mathrm{He}$ was honoured by his colleagues and the citizens of St. John on his anniversaries of 40 years, 50 years and 60 years of active medical practice.

\section{Discussion}

The information presented in the second part of this historical revicw became known to the author while compiling a history of the Department of Anaesthesia at the Saint John Regional Hospital.

The precedence of Crawford Long and William Morton is well established, as is the sequence of events leading to the simultaneous introduction of ether anaesthesia in Scotland and England. However, bearing in mind the relative importance of St. John in 1846 (pre-confederation), as compared to its present status, it seems reasonable to postulate that, if London and Dumfries received the news from Boston on December 16, 1846, ${ }^{4,16}$ carried by the Acadia which called at Halifax 13 days earlier, St. John could have and indeed did receive the news 10 o'clock Monday night December 7, $1846{ }^{19}$

Early anaesthesia in St. John was not an accident. Following the American Revolution (1755-1781) thousands of Loyalists left the United States for Canada and 
St. John soon became known as the Loyalist City. The immigrants were mainly from New York, New Jersey and New England. As the early history of anacsthesia in the United States, Canada and England was directly associated with dentistry, and almost half of the dentists practicing in St. John between 1823 and 1880 trained in Boston, it would be logical to expect early dental general anaesthesia in St. John. While the medical profession was mainly trained in England and Scotland, the dental profession was exclusively American-trained and in most cases were Americans. Considering the commercial, medical, dental and cultural relationships between St. John and Boston, the presence in St. John of some outstanding dental and medical practitioners; the printing of Dr. Bigelow's lecture from the Boston Medical and Surgical Journal in the St. John papers and the arrival of the news in St. John nine days before it reached Liverpool, the sequence of events seems logical.

Furthermore, there is documentary evidence that ether anaesthesia was used for dentistry in St. John in 1844 by Dr. VanBuskirk and Dr. William Bayard. ${ }^{22}$ This was after Crawford Long and Horace Wells, but some time before William Morton anaesthetised Gilbert Abbott in Boston. If indeed this is one of the VanBuskirk brothers, specifically the Lawrence VanBuskirk referted to by $D r$. Daniel McNeill Parker in his memoirs, ${ }^{33}$ then the uncertain date mentioned by Parker as being the first in Nova Scotia would seem to be 1850 or later, since Dr. McAveney relates that prior to 1850 the VanBuskirks were still in St. John ${ }^{21}$ Support is given to this by Gullett. In 1856 George Vanbuskirk of St. John moved to Montreal to take over the practice of W.H. Elliott. ${ }^{34,35}$

Thus the evidence presented here indicates that the first use of ether anaesthesia for general surgery in Canada was for the removal of a tumour of the arm. The patient was a Mr. Beatteay of Carleton, which is now West Saint John. The surgeon was Dr. Hunter Peters and the anaesthetist Dr. Cyrus Fiske, a St. John Dental Surgeon who was supervised by Dr. Samuel Adams of Boston. Three medical men, one of whom was probably Dr. Peters' brother and other witnesses observed the procedure. They and the patient were perfectly satisfied with the complete and entire insensibility to pain. The operation took place on Monday, January 18, 1847

\section{References}

I Long $C W$. An account of the first use of sulphuric ether by inhalation as an anaesthetic in surgical operations. South. Med. Surg. J., 1849; 5: 705-13.

2 Keys $T E$. The History of Surgical Anaesthesia. New York, N.Y. Schuman's 1945; $21-2$.

3 Anonymous. Insensibility During Surgical Operations
Produced by Inhalation. The Weekly Chronicle 1846; Dec 18:1 (Col 4, 5, 6) $2(\mathrm{Col} \mathrm{1,2).}$

4 Sykes WS. Essays on the First Hundred Years of Anaesthesia, Vo1. 1, Churchill Livingstone Edinburgh, London, Melbourne and New York. 1982: 51.

5 Matsuki A. A chronology of the very early history of inhalation anaesthesia in Canada. Can Anaesth Soc J, 1974; 21, 92-5.

$6 \mathrm{Br} \mathrm{Am} \mathrm{J} \mathrm{1846;} \mathrm{2:} 226$.

7 Br Am J 1847; 2: 247.

$8 \mathrm{Br} \mathrm{Am} \mathrm{J} \mathrm{1847;} 3: 34$

9 Br Am J 1847; 3: 10

10 Jacques $A$. Anaesthesia in Canada, 1847-1967: 1. The beginnings of anaesthesia in Canada. Can Anaesth Soc J 1967; 14: 500-9.

$11 \mathrm{Br}$ Am J 1847; 2: 338

$12 \mathrm{Br} \mathrm{Am} \mathrm{J} \mathrm{1847;} \mathrm{2:} 304$

$13 \mathrm{Br} \mathrm{Am} \mathrm{J} \mathrm{1847;} \mathrm{3:} 199$.

14 Wright DJ. The early history of andesthesia in Newfoundland. Can Anaesth Soc J 1979; 26: 231-8.

15 Sykes WS. Essays on the First Hundred Years of Anaesthesia, Vol. 1, Churchill Livingstone Edinburgh, London, Melbourne and New York. 1982; 52.

16 Ellis $R H$. The introduction of ether anaesthesia to Great Britain. Anaesthesia 1976; 31: 766.

17 Raddall TH. Warden of the North. McClelland and Stewart. 1971: 194.

18 Shipping Intelligence. The Nova Scotian (Halifax) 1846; December 7, $\mathrm{Pg}$ 3. col. 4 .

19 The Morning News (Saint John) Wednesday, December 9th, 1846; p. 2. col. 1 .

$20 O^{\prime} B r i e n$ F. Old Papers and Early Joumalists. The Citizen 1985; 18: 4 (Col 1, 2).

21 McAvenney AF. Dentistry in St. John, Saint John Globe 1905 Sept 8, $19052(\mathrm{Col} \mathrm{3,} \mathrm{4,} \mathrm{5,} \mathrm{6).}$

22 McAvenney AF. Early History of Dentistry in Saint John. Dominion Dental Journal 1905; Vol 17, 431-8.

23 The Weekly Chronicle (St. John) Friday, January 22, 1847, p. 2 col. 4.

24 The Phoenix Advertiser, Saturday, January 23, 1847, p. 2 col. 3.

25 The St. John Globe, March 25, 1911. Old Times in St. John by Clarence Ward $(\mathrm{Col} 3,4,5)$.

26 Ward $C$. Scrapbook (Small), shelf 19, p. 91, New Brunswick Museum.

27 The New Brunswick Courier, December 6, 1845, p. 2 col. 5.

28 The New Brunswick Courier, Saturday, December 12 , 1846 , p. 4 col. 1.

29 The New Brunswick Courier, Saturday, December 12, 1846 p. 1 col. 5.

30 The New Brunswick Courier, Saturday, April 2, 1842 p. 1 col. 3 . 
31 The Nova Scotian, December 7, 1846 p. 7 col. 3.

32 Saint John Globe, March 22nd, 1847, original reference as stated by C. Ward in Saint John Globe 1911, Feb 4 (col $3,4,5)$.

33 Stewart WB. Medicine in New Brunswick. The New Brunswick Medical Society. 1974: 286.

34 Parker WE. Daniel McNeill Parker M.D. His Ancestry and A Memoir of His Life. Toronto, William Briggs. 1910: 394

35 Gulletr $D W$. A History of Dentistry in Canada. $\mathrm{U}$ of Toronto Press 1971 p 29.

\section{Résumé}

Onfait la révision de la documentation portant sar les débuts de l' aresthésie à l'éther au Nouveau-Brurswick qui était, jusqu' en 1867, une colonie anglaise faisant partie de l'Amérique Britannique du Nord. Il existe une preuve documentaire que la première anesthésie a l'éther pour chirurgie dentaire fut administrée en 1844 à Saint-Jean. Nouveau-Brunswick, dans le pays qui se nomme maintenant Canada. Il existe aussi une presve documentaire que la première anesthêsic à l'éther pour chirurgie générale fut administrée d̀ Saint-Jean, le 8 janvier 1847, plutôt qu'à Montréal en mars 1847.

\section{Dedication}

I would like to dedicate this article to my many former chiefs. I was blessed to have worked with such a distinguished group of Physicians. May we all meet again in Heaven.

Dr. Wesley Bourne

St. Mary's Hospital, Montreal

Dr. Digby Leigh

Children's Hospital, Montreal

Dr. Kathleen Belton

Children's Hospital, Montreal

Dr. Harold Griffith

Homeopathic Hospital, Montreal and R.C.A.F.

Dr. Ned Lunney

Saint John General Hospital

Dr. Fred Jennings

Saint John General Hospital

Dr. Ralph Connell

Saint John General Hospital

Dr. Eli Davis

Saint John General Hospital

Dr. Preston Leavitt, Present Chief

Saint John Regional Hospital

\section{Acknowledgements}

To the staffs of the following Libraries I am deeply grateful for their real help to a retired novice:
Saint John Free Public Library; Dr. Carl R. Trask Health Sciences Library; New Brunswick Mușeum Library; W. K. Kellogg Health Sciences Library; Halifax City Regional Library; New Brunswick Archives Dept. of Historical and Cultural Resources; Ward Chipman Library, University of New Brunswick, Saint John; University of New Brunswick Library; Salem Public Library and the Essex Institute, Salem, Massachusetts; The Francis A. Countway Library of Medicine and the Boston City Library, Boston, Massachusetts.

\section{Sincere thanks to:}

Dr. Ian Keith, Department of Anaesthesia, Saint John Regional Hospital; Dr. Peter Toner, Professor, Department of History, University of New Brunswick, Saint John; Dr. Oskar Sykora, Faculty of Dentistry, Dalhousie University; Dr. A.D. Gibbon and Frank O'Brien, two local historians; Mrs. Barbara McCrossin, Secretary, Department of Anaesthesia, Saint John Regional Hospital; Mr. Donald Ward, artist; Mr. Brian Daley and staff of the Media Productions Department, Saint John Regional Hospital; Mr. and Mrs. W. Foster Hammond (present owners of the Peters House).

\section{Appendix}

NAMES OF THE NEWSPAPERS

Saint John, New Brunswick

The Saint John Globe

The Weekly Chronicle

The Phoenix Advertiser

The New Brunswick Courier

The Saint John Morning News

Halifar, Nova Scotia

The Nova Scotjan

St. John's Newfoundland

The Public Ledger

Liverpool (England)

The Liverpool Mercury

Salem, Massachusetts

The Salem Register

Boston, Massachusetts

The Boston Daily Advertiser

Boston Shipping List

Boston Courier 